\title{
BILINGUALISM IN THE ENGLISH OF TERTIARY STUDENTS: A SINE-QUA-NON FOR MENTORSHIP AND ENTREPRENEURIAL DEVELOPMENT
}

\section{EZENWA YOUNG OBIOHA AND OSITADINMA CHINENYE OBIOHA}

(Received 12 November 2014; Revision Accepted 28 December 2014)

\begin{abstract}
Effects of Bilingualism on the English of Tertiary Students as a mentorship and entrepreneurial tool were investigated. The term bilingualism is the use of two languages (repertoire) of an individual or a speech community. An important feature of bilingualism is that it is a consequence of language in contact which deals with the direct or indirect influence of one language on the other. Five research questions were used to investigate the effects of Bilingualism on the English of tertiary students. A total of three hundred students from two tertiary institutions were used. Fifty percent $(50 \%)$ and above is regarded as a pass mark proving the effects of bilingualism on the English of tertiary students. The selected tertiary institutions are run by the State and Federal Governments. The data interpretation proved that bilingualism has overriding positive mentorship and entrepreneurial influence on students' development. These benefits include enhancing and enriching the students' language experiences/structure, offering insights and opportunities for developing cognitive skills, enhancing ability to interact in both languages, transfer concepts from one language to the other and a means of cultural transmission. Based on these findings, recommendations such as encouraging parents to maintain bilingualism at home and schools, language teachers to emphasis areas of difficulty and interference, more emphasis to be made by textbook writers, syllabus designers, curriculum planners, provision of instructional materials and financial assistance by the government were made to enhance proficiency.
\end{abstract}

KEYWORDS: Bilingualism, Mentorship, Entrepreneurial development, English, Tertiary Students, Sine-qua-non.

\section{INTRODUCTION}

One striking characteristic of a human being and something that distinguishes him from any other animal is the ability to use language in its most dynamic form namely speech. Every human society possesses a language, which is physiologically expressed in the vocal system and used in exchanging views about the universe. Anyanwu $(2002: 24,25)$ posits that no human being is born speaking a language meaning that language is not inherited. However, every normal human person is born with the capacity to master the language spoken in his immediate environment and he achieves this complex task over time starting from the moment of his birth such that by the time he has attained six years and above he has become a user of that language. Akindele and Adegbite (1999) opine that language is characterized by a set of vocal sounds which can be decoded. These are produced by the human organs of speech-lips, tongue, larynx etc. The vocal sounds produced by the vocal organs are used in various

Ezenwa Young Obioha, Federal University of Technology Owerri, Nigeria.

Ositadinma Chinenye Obioha, Government Secondary School, Emeabiam, Imo State, Nigeria. 
systematic and rule-governed combinations. Language is thus a human phenomenon that has form which can be described in terms of the unit of sounds (phonemes), words, morphemes, phrases, sentences and paragraph or discourse.

Language is the source of human life and

power' Fromkin and Rodman (1978). This definition suggests about five characteristics of language which include that: language is conventional, systematic, habitual, a vocal behaviour and a means of communication. Yule (1996: 25) identified the unique properties of human language as follows: displacement, arbitrariness, creativity, discreetness, duality and cultural transmission. In summary, it can be described as system of sounds or vocal symbols by which human beings communicate experience. It is specie-specific to man. Man uses language to communicate his individual thoughts, inner feelings, personal psychological experiences and business entrepreneurial activities. Thus bilingualism promotes mentorship and entrepreneurial skills in the life of the tertiary student. Nwachukwu (2007:15) opines that English has remained the primary language of education right from the colonial era. The language provisions of the National Policy on education (2004) clearly defines the functions of English in primary education in Nigeria thus:

The medium of instruction in the primary school shall be the language of the environment for the first three years. During this period,

English shall be taught as a subject.

According to this National Policy on Education, the mother tongue is the medium of instruction in lower primary while English is studied as a school subject at this stage.

\subsection{English and Government}

English is the primary language of officialdom in Nigeria. Although there is no rule that forbids the use of indigenous languages in official transactions, English has remained the language of official documentation and general official transactions. Ogu (1992:93) states that ".... The stand of government policy is that English is the national language in Nigeria and to be used in political administration and for education purposes". Section 51 of the Constitution of the Federal Republic of Nigeria states that:

The business of the National Assembly shall be conducted in English, Igbo,
Hausa and Yoruba when adequate arrangements have been made.

\subsection{The Notion of Bilingualism On Mentorship and Entrepreneurial Development}

Bilingualism is described as the ability of an individual to produce update meaningful utterances in the other language. An important feature of Bilingualism is that it is a consequence of language in contact, which deals with the direct or indirect influence of one language on the other. Osuafor (2002:196) stated that in Nigeria, there is contact between the English language and the Vernacular of the different ethnicities. And the result is the presence of people who are users of both their vernaculars (L1) and the English language (L2) in the country. Thus, there are Igbo - English, Yoruba - English, Hausa English bilinguals and so on.

Each of the two languages in Bilingualism has its own distinct phonological, lexical, grammatical and discourse rules. Each, therefore, forms a code of communication which aids in the mentorship and entrepreneurial development of the user or users. Examples of Bilingual speech communities are Canada where English and French are considered very important to the life of the people; Nigeria where several bilingual speech communities exist for example: Hausa/Kanuri, Igbo/English, Yoruba/English etc,

\subsection{THE ORIGIN OF BILINGUALISM}

The genesis of bilingualism could be traced to the following factors namely; colonialism, conquest, trade/commerce, federation and amalgamation, annexation and border line areas (Akindele and Adegbite 1999:28). It is also possible for bilingualism to originate by migration/immigration. For example, the $19^{\text {th }}$ century and $20^{\text {th }}$ century European and Chinese migration to the U.S.A (Akindele \& Adegbite, 1999:29).

\subsection{EFFECTS OF BILINGUALISM ON THE ENGLISH OF TERTIARY STUDENTS}

Bilingualism has both positive and negative effects on the English of tertiary students. The positive effects, which can also be called Benefits of bilingualism, are as follows: language development as a whole including the first language. When learning two languages at the same time, the learner becomes aware of language itself, having two or more words for 
each object, idea or concept will expand rather than contract the mind. There will be transfer in thinking from one language to another that is if a child is taught Mathematical multiplication and division in one language. Those skills do not have to be re-taught in the second language. Wardhaugh (2010:97), Bilinguals appear to develop a more analytical orientation to language due to their experience in organizing their two language systems and keeping them separate while they perform particular tasks. Much of the research on cognitive aspects of second language learning has focused on creative divergent thinking and many studies indicate a bilingual advantage in these areas (Bialystok, 2001).

Academic and cognitive skills transfer readily between language while there may be differences in the vocabulary, grammar and writing systems of languages. Bilingualism has cognitive advantages particularly in domains such as helping students understand the arbitrary nature of language systems. Obviously, the major positive consequence of bilingualism is knowing two languages and thus being able to converse with a larger array of individuals, as well as having access to two cultures, two bodies of literature and two worldviews.

Speaking other languages also has economic advantages as bilinguals are in high demand in the new global economy. There is also considerable evidence that many key literacy-related skills, including phonological awareness, print concepts, decoding skills and extended discourse are transferable from L1 to L2. Thus, they can enhance mentorship and entrepreneurial development skills more readily than in a monolingual individual, community or system.

Code-switching, code-mixing,interference of L1 on L2, code-borrowing, bilingualism and biculturalism. The formal type of code-switching refers to the linguistic realization of codeswitching from one language to the other. Code switching in this formal type refers to a complete change from one language ' $A$ ' to another language ' $B$ '. There is instead a blend of the two codes of communication involved in the communicative process. An inter-sentential code change realizes a switch that takes place across sentences. Code-Mixing refers to a situation whereby two languages are used in a single sentence within major and minor constituent boundaries. Interference of $L_{1}$ on $\mathbf{L}_{2}$ : This refers to those instances of deviation from the norms of either language which occur in the speech of bilinguals as a result of their familiarity with more than one language. Two types of interference can be distinguished, the 'Proactive' Interference or positive transfer or facilitation. This is an interference phenomenon that helps in the acquisition of the target language. And the 'Retroactive' or negative transfer or interference is one that retards the process of the acquisition of the target language. Other types of interference include: phonological, morphological, grammatical and semantic interferences.

\subsection{Code Borrowing}

Borrowing can be defined as the occasional use of items from one language in utterances of another language (Akindele and Adegbite, 1999:43). This arises out of the fact that there is no language in the world that can be regarded as self-sufficient and as such every language borrows from another.

Borrowing cannot be regarded as a feature of bilingualism or multilingualism alone, it is also a feature of monolingualism. In monolingual speech in English, we have such lexical items as 'resume', 'elite' which are borrowed into English. In the Nigerian context, each of the indigenous languages borrowed from one another e.g. the words 'wahala', and 'seria' are borrowed from Hausa into Yoruba.

\subsection{Bilingualism-Biculturalism}

It has already been said that language reflects, expresses and records culture. The possession of a language inevitably means the acquisition of a culture. However, while we can say that a monolingual person is essentially monocultural not all bilinguals can be said to be bicultural, except a coordinate bilingual, since bilingualism and biculturalism are not coextensive.

\subsection{STATEMENT OF THE PROBLEM}

An important feature of bilingualism is that it is a consequence of language in contact which deals with the direct and indirect influence of one language on the other. The imposition of English language in Nigeria by the colonial masters institutionalized bilingualism. English language functions as official language and a lingua franca in Nigeria and is learnt as a second language (L2) among other indigenous languages yet the level of proficiency is still below standard. This problem is of great concern to the linguists and researchers. This research is, 
therefore, an attempt to investigate the effects of bilingualism on the English of tertiary students and how this can enhance mentorship and entrepreneurial development.

\subsection{Purpose / Significance Of The Study}

The research investigates the effects

Bilingualism has on the English of tertiary students as a mentorship and entrepreneurial development tool and also to proffer solutions that will help in achieving proficiency in the languages. It is believed that the research findings will:

Expose learners of English language to areas of difficulty/interference which hinders the achievement of proficiency in the language and possibly proffer solutions to these problems. Aid English language teachers to lay emphasis on areas of difficulty and drill the learners on the correct forms. Create awareness to the learners, teachers, society and the users of the language. enlighten the syllabus designers, text book writers and curriculum planners on more areas of emphasis in order to ameliorate the negative effects. Enlighten the government on deploying qualified and competent teachers in the teaching of the language.

\subsection{Research Questions}

This research is designed to find answers to the following questions:

1. Does bilingualism aid the learning of English of tertiary students?

2. Does code-switching and code-mixing affect the English of tertiary students?

3. How does mother tongue (MT or L1) interfere with the acquisition of proficiency in the learning of English of tertiary students?

4. Does code-borrowing affect English language learning?

5. Does culture affect tertiary students' English?

6. Does bilingualism enhance the development Mentorship and Entrepreneurial Skills in Tertiary Students?

\subsection{Limitation / Scope Of The Study}

This study is limited to the study of effects of Bilingualism on the English of tertiary students and their mentorship and entrepreneurial development. The emphasis is on the positive effects of bilingualism on the English of tertiary students. The population of the study is made up of students from the Department of English and Literary Studies, Imo State University and Department of English Language Studies, Alvan Ikoku Federal College of Education, Owerri. This study is carried out through the administration and collection of questionnaire by the researchers.

\subsection{THEORETICAL FRAMEWORK}

The theoretical framework of this study hinges on the Speech Act Theory. This theory was first introduced by a British language philosopher known as J.L. Austin in his book How to do things with Words (1962). Major concerns of Speech Act Theory is to analyze the roles that utterances play in relation to the behaviour of speakers and hearers in interpersonal communication. Searle (1969) claims that there are five major types of actions that human beings can perform by the use of language. These are representative, declarative, directive, expressive and commissive.

\subsection{Speech Act Theory}

In speech act theory, a three-way distinction is often made between acts caused by the speaker in uttering a sentence. These are locutionary, illocutionary and perlocutionary acts: Grice in (1975) amplified the Speech Act Theory and postulates four conversational maxims. Conversational maxims are those rules which people follow or obey during a talk exchange. The four major types of conversational maxims recognized by Grice (1975) are: (i). The Maxim of Quantity, (ii). The Maxim of Quality, (iii). The Maxim of Manner, and (iv). The Maxim of Relevance. Details of these can be seen in Grice (1975).

Code-switching is a conversational strategy used to establish, cross or destroy boundaries, to create, evoke or change interpersonal relations with their rights and obligations (Gal, 1978:247). Code-switching and code-mixing sometimes serve a linguistic need of providing lexical, phrasal or sentential filler in an utterance or when there is lack of facility in a language. They are also used in quoting someone and also qualifying (amplifying or emphasizing) points of utterances.

\subsection{Technique For Data Collection}

The research adopted the use of questionnaire in the collection of data. The students were encouraged to freely answer the structured questions since some were reluctant 
to do so. The demand of the study was to get accurate responses from the entire population for objective analysis of the result.

\subsection{Population of the Study}

The population chosen for this study was made up of students of English Department in two tertiary institutions in Imo. From these institution, a total of three hundred (300) bilingual students were randomly selected, 200 students were females while one hundred (100) were males. These were from eighteen (18) states of the federation including Imo, Abia, Anambra, Enugu, Rivers, Bayelsa, Akwa lbom, Kaduna, Ebonyi, Calabar, Lagos, Delta, Edo, Ogun, Oyo, Kano, and Bornu. The population fairly represents the three major language groups in the country.

\subsection{Testing Instrument}

The testing instrument used for the purpose of data collection was the questionnaire. Twenty five (25) questions were constructed and distributed to the students. The structure of the questionnaire used was direct questions offering the respondents an opportunity to indicate 'Yes' or 'No' as answers. The 'Yes/No' nature of the questions enhanced the administration and assessment of the data collected. The questions were based on the different effects bilingualism has on the English of tertiary students. The researchers distributed the questionnaire to students in the two tertiary institutions and collected them back after the students' responses for accurate result. The Percentage score (x100/n) as determined to establish the students' $\%$ responses. The questions were arranged in a tabular form showing the number of responses; that is the number that responded yes/no and the percentage.

\subsection{DATA ANALYSIS INTERPRETATION}

This chapter discusses the data collected and the result of the study. The researchers structured the questionnaire in such a way that the questions would help them to get answers to each research question. The data are organized in tables showing the questions, the options, number of respondents and percentage responses. The data presented in the following tables $4.1,4.2,4.3,4.4$ and 4.5 were statistically analyzed. The results of the analyses and the interpretation were systematically presented.

Table 4.1: Research Question 1: Does Bilingualism aid the English of Tertiary Students?

\begin{tabular}{|c|c|c|c|c|}
\hline $\mathbf{S} / \mathbf{N}$ & QUESTION ITEMS & OPTIONS & RESPONDENTS & $\begin{array}{l}\% \\
\text { RESPONSES }\end{array}$ \\
\hline \multirow[t]{2}{*}{1.} & Do you speak more than one language? & $\begin{array}{l}\text { Yes } \\
\text { No }\end{array}$ & $\begin{array}{l}300 \\
-\end{array}$ & $\begin{array}{l}100 \\
-\end{array}$ \\
\hline & & Total & 300 & 100 \\
\hline \multirow[t]{2}{*}{2.} & $\begin{array}{l}\text { Can you speak the two languages } \\
\text { fluently? }\end{array}$ & $\begin{array}{l}\text { Yes } \\
\text { No }\end{array}$ & $\begin{array}{l}235 \\
65\end{array}$ & $\begin{array}{l}78 \\
22\end{array}$ \\
\hline & & Total & 300 & 100 \\
\hline \multirow[t]{2}{*}{3.} & $\begin{array}{l}\text { Does bilingualism enhance the ability of } \\
\text { ransferring concepts from one language } \\
\text { to the other? }\end{array}$ & $\begin{array}{l}\text { Yes } \\
\text { No }\end{array}$ & $\begin{array}{l}250 \\
50\end{array}$ & $\begin{array}{l}83 \\
17\end{array}$ \\
\hline & & Total & 300 & 100 \\
\hline \multirow[t]{2}{*}{4.} & $\begin{array}{l}\text { Does the ability to interact in two } \\
\text { languages aid English language } \\
\text { proficiency of tertiary students? }\end{array}$ & $\begin{array}{l}\text { Yes } \\
\text { No }\end{array}$ & $\begin{array}{l}260 \\
40\end{array}$ & $\begin{array}{l}87 \\
13\end{array}$ \\
\hline & & Total & 300 & 100 \\
\hline \multirow[t]{2}{*}{5.} & $\begin{array}{l}\text { Does bilingualism enhance and enrich } \\
\text { the students' language experience and } \\
\text { offer them opportunities for development } \\
\text { pf cognitive and mentorship skills? }\end{array}$ & $\begin{array}{l}\text { Yes } \\
\text { No }\end{array}$ & $\begin{array}{l}260 \\
40\end{array}$ & $\begin{array}{l}87 \\
13\end{array}$ \\
\hline & & Total & 300 & 100 \\
\hline
\end{tabular}


Table 4.2: Research Question 2: Does code-mixing and code-switching affect the English of tertiary

\begin{tabular}{|c|c|c|c|c|}
\hline $\mathbf{S} / \mathbf{N}$ & QUESTION ITEMS & $\begin{array}{l}\text { OPTION } \\
\mathrm{S}\end{array}$ & $\begin{array}{l}\text { RESPONDENT } \\
\mathrm{S}\end{array}$ & $\begin{array}{l}\text { \% } \\
\text { RESPONSES }\end{array}$ \\
\hline \multirow[t]{2}{*}{6.} & $\begin{array}{l}\text { Do you agree that students/people generally } \\
\text { code-mix and code-switch in informal } \\
\text { conversations? }\end{array}$ & $\begin{array}{l}\text { Yes } \\
\text { No }\end{array}$ & $\begin{array}{l}286 \\
14\end{array}$ & $\begin{array}{l}95 \\
5\end{array}$ \\
\hline & & Total & 300 & 100 \\
\hline \multirow[t]{2}{*}{7.} & $\begin{array}{l}\text { Are code-mixing and code-switching among } \\
\text { tertiary students done in order to play-down } \\
\text { on their language? }\end{array}$ & $\begin{array}{l}\text { Yes } \\
\text { No }\end{array}$ & $\begin{array}{l}240 \\
60\end{array}$ & $\begin{array}{l}80 \\
20\end{array}$ \\
\hline & & Total & 300 & 100 \\
\hline \multirow[t]{2}{*}{8.} & $\begin{array}{l}\text { Is it true that mixing and switching codes are } \\
\text { unconscious attitudes among bilinguals? }\end{array}$ & $\begin{array}{l}\text { Yes } \\
\text { No }\end{array}$ & 180 & $\begin{array}{l}60 \\
40\end{array}$ \\
\hline & & Total & 300 & 100 \\
\hline \multirow[t]{2}{*}{9.} & $\begin{array}{l}\text { Do you mix-codes or switch-codes when you } \\
\text { are speaking to another student of the same } \\
\text { bilingual background? }\end{array}$ & $\begin{array}{l}\text { Yes } \\
\text { No }\end{array}$ & 280 & 93 \\
\hline & & Total & 300 & 100 \\
\hline
\end{tabular}

Table 4.3: Responses to Research Question 3: How does mother tongue (MT or L1) interfere with the acquisition of proficiency in the English of tertiary students?

\begin{tabular}{|c|c|c|c|c|}
\hline $\mathbf{S} / \mathbf{N}$ & QUESTION ITEMS & $\begin{array}{l}\text { OPTION } \\
\text { S }\end{array}$ & $\begin{array}{l}\text { RESPONDENT } \\
\mathrm{S}\end{array}$ & $\begin{array}{l}\% \\
\text { RESPONSE } \\
S\end{array}$ \\
\hline \multirow[t]{2}{*}{10} & $\begin{array}{l}\text { Are some phonemes present in English } \\
\text { language absent in your mother tongue? }\end{array}$ & $\begin{array}{l}\text { Yes } \\
\text { No }\end{array}$ & $\begin{array}{l}292 \\
8\end{array}$ & $\begin{array}{l}97 \\
3\end{array}$ \\
\hline & & Total & 300 & 300 \\
\hline \multirow[t]{2}{*}{11} & $\begin{array}{l}\text { Do you find it difficult to distinguish } \\
\text { between the pronunciation of some } \\
\text { English words because of the mother } \\
\text { tongue influence, like seat and sit etc.? }\end{array}$ & $\begin{array}{l}\text { Yes } \\
\text { No }\end{array}$ & $\begin{array}{l}235 \\
65\end{array}$ & $\begin{array}{l}78 \\
22\end{array}$ \\
\hline & & Total & 300 & 100 \\
\hline \multirow[t]{2}{*}{12} & $\begin{array}{l}\text { Do you think that lack of correspondence } \\
\text { between systems (such as articles, } \\
\text { pronouns, tense, concord etc) is the } \\
\text { main source of interference at the } \\
\text { grammatical level? }\end{array}$ & $\begin{array}{l}\text { Yes } \\
\text { No }\end{array}$ & $\begin{array}{l}296 \\
4\end{array}$ & $\begin{array}{l}99 \\
1\end{array}$ \\
\hline & & Total & 300 & 100 \\
\hline
\end{tabular}


Table 4.4: Responses to Research Question 4: Does code-borrowing affect the English of tertiary

\begin{tabular}{|c|c|c|c|c|}
\hline $\mathbf{S} / \mathbf{N}$ & QUESTION ITEMS & OPTIONS & RESPONDENTS & $\begin{array}{l}\% \text { RESPONSE } \\
\mathrm{S}\end{array}$ \\
\hline \multirow[t]{2}{*}{13} & $\begin{array}{l}\text { Borrowed words pose problems } \\
\text { for the learner. Do you agree? }\end{array}$ & $\begin{array}{l}\text { Yes } \\
\text { No }\end{array}$ & $\begin{array}{l}274 \\
26\end{array}$ & $\begin{array}{l}91 \\
9\end{array}$ \\
\hline & & Total & 300 & 300 \\
\hline \multirow[t]{2}{*}{14.} & $\begin{array}{l}\text { Can borrowing occur in either of } \\
\text { the two languages? }\end{array}$ & $\begin{array}{l}\text { Yes } \\
\text { No }\end{array}$ & $\begin{array}{l}297 \\
3\end{array}$ & $\begin{array}{l}99 \\
1\end{array}$ \\
\hline & & Total & 300 & 100 \\
\hline \multirow[t]{2}{*}{15} & $\begin{array}{l}\text { Do you agree that no language } \\
\text { in the world is self-sufficient and } \\
\text { as such every language borrows } \\
\text { from one another? }\end{array}$ & $\begin{array}{l}\text { Yes } \\
\text { No }\end{array}$ & $\begin{array}{l}245 \\
55\end{array}$ & $\begin{array}{l}82 \\
18\end{array}$ \\
\hline & & Total & 300 & 100 \\
\hline \multirow[t]{2}{*}{16} & $\begin{array}{l}\text { Does the indigenous languages } \\
\text { borrow from one another? }\end{array}$ & $\begin{array}{l}\text { Yes } \\
\text { No }\end{array}$ & $\begin{array}{l}282 \\
18\end{array}$ & $\begin{array}{l}94 \\
6\end{array}$ \\
\hline & & Total & 300 & 100 \\
\hline \multirow[t]{2}{*}{17} & $\begin{array}{l}\text { Have these words been } \\
\text { indigenized? mekaniiki } \\
\text { (mechanic), redio (radio), video } \\
\text { (video), pilo (pillow) }\end{array}$ & $\begin{array}{l}\text { Yes } \\
\text { No }\end{array}$ & $\begin{array}{l}258 \\
42\end{array}$ & $\begin{array}{l}86 \\
14\end{array}$ \\
\hline & & Total & 300 & 100 \\
\hline
\end{tabular}

Table 4.5: Responses to Research Question 5: How does culture affect the English of tertiary students?

\begin{tabular}{|c|c|c|c|c|}
\hline $\mathbf{S} / \mathbf{N}$ & QUESTION ITEMS & OPTIONS & $\begin{array}{l}\text { RESPONDE } \\
\text { NTS }\end{array}$ & $\begin{array}{l}\text { R } \\
\text { RSPONSES }\end{array}$ \\
\hline \multirow[t]{2}{*}{18} & $\begin{array}{l}\text { Language reflects, expresses and records } \\
\text { culture. Do you ag ree? }\end{array}$ & $\begin{array}{l}\text { Yes } \\
\text { No }\end{array}$ & $\begin{array}{l}292 \\
8\end{array}$ & $\begin{array}{l}97 \\
3\end{array}$ \\
\hline & & Total & 300 & 300 \\
\hline \multirow[t]{2}{*}{19} & $\begin{array}{l}\text { Is it true that language cannot be } \\
\text { separated from its social and cultural } \\
\text { contexts of use? }\end{array}$ & $\begin{array}{l}\text { Yes } \\
\text { No }\end{array}$ & $\begin{array}{l}295 \\
5\end{array}$ & $\begin{array}{l}98 \\
2\end{array}$ \\
\hline & & Total & 300 & 100 \\
\hline \multirow[t]{2}{*}{20} & $\begin{array}{l}\text { Is culture fundamental to the way we } \\
\text { speak, write, listen and read? }\end{array}$ & $\begin{array}{l}\text { Yes } \\
\text { No }\end{array}$ & $\begin{array}{l}225 \\
75\end{array}$ & $\begin{array}{l}75 \\
25\end{array}$ \\
\hline & & Total & 300 & 100 \\
\hline \multirow[t]{2}{*}{21} & $\begin{array}{l}\text { Do you agree that a coordinate bilingual is } \\
\text { said to be bicultural? }\end{array}$ & $\begin{array}{l}\text { Yes } \\
\text { No }\end{array}$ & $\begin{array}{ll}253 \\
47\end{array}$ & $\begin{array}{l}84 \\
16\end{array}$ \\
\hline & & Total & 300 & 100 \\
\hline \multirow[t]{2}{*}{22} & $\begin{array}{l}\text { Does the acquisition of native language } \\
\text { (L1) interfere with the learning of the } \\
\text { target language and its culture? }\end{array}$ & $\begin{array}{l}\text { Yes } \\
\text { No }\end{array}$ & $\begin{array}{l}288 \\
12\end{array}$ & $\begin{array}{l}96 \\
4\end{array}$ \\
\hline & & Total & 300 & 100 \\
\hline
\end{tabular}

\subsection{Interpretation of Data}

A research on the effects of bilingualism on the English of tertiary students and its effects on the mentorship and entrepreneurial development of tertiary students has been carried out. From the responses obtained from the data collected and analyzed, it was observed that the information in table 4.1, question 1, indicates that all the tertiary students in the two tertiary institutions were all bilinguals. They are all 
Nigerians from different states of the federation. Nigeria is known to be multilingual and for these students learning English as a second language in the English Departments, means they have already acquired the native language (L1). This buttresses the views of Akindele and Adegbite (1999: 28) that bilingualism is the use of two languages by an individual or speech community. The data shows that bilingualism in tertiary institutions can enhance mentorship and entrepreneurial skills better and faster. In question 2 of table 4.1, it was also observed that 78 percent of the sampled population speak the two languages fluently, while only 22 percent cannot speak the two languages fluently. It is this type of language behaviour that Osuafor (2002:199) identifies as subordinate bilingualism in Nigerian educational system, and ranging from the nursery to the university level

From table 4.1, question 3, 83 percent of the population responded positively, thus corroborating the evidence that bilingualism enhances the ability of transferring concepts from one language to the other. Baker (2006: 330) agrees to this view that concepts and strategies transfer easily from one language to another. The data represented in table 4.2 question 4 , show that the ability to interact in the two languages aid English language proficiency of tertiary students in that 88 percent of the respondents are in agreement while 13 percent disagree.

Table 4.1 question 5, clearly shows that bilingualism enhances and enriches the students' language experience and offers them insights and opportunities for development of cognitive skills. 85 percent of the respondents agree to this view while 15 percent of the respondents are not in agreement. Liddicoat (2001, 2002:14,15) buttresses this point that exposure to another language helps the student to learn the nature of language and develop additional insights into the nature of language. He went further to say that it enhances language experiences, gives unique insights and opportunities for development of cognitive skills.

Osuafor (2002:196-197) asserts that since vernacular had contact with the English language, we now have Igbo-English, YorubaEnglish and Hausa-English. Similarly, Anyanwu (2002:39) observes the existence of Engligbo, Engliausa and Englioruba etc, all indicating that code-mixing and code-switching are not more pronounced in the English of tertiary students than other linguistic groups.
Observation from Tables $4.2 ; 4.3 ; 4.4$ and 4.5 , question $4,5,6$, al show positive responses ranging from 78 to 97 percent of the sample population. Thus all believing, concurring and corroborating the believe that bilingualism is a sine-qua-none for mentorship and entrepreneurial development among students of tertiary institutions.

\subsection{SUMMARY, RECOMMENDATIONS AND CONCLUSION}

\subsection{Summary}

This research work has investigated the effects of bilingualism on the English of tertiary students and their effect on mentorship and entrepreneurial development. The researchers had undertaken a background study into the field of sociolinguistics in chapter one by examining pertinent terms as language, the status or role of English language in Nigeria, language acquisition, English as a lingua Franca in Nigeria, the notion of bilingualism, its origin or causes, its outcome and extent, the benefits or positive and negative effects of bilingualism on the English of tertiary students. Chapter two looked at the theoretical and empirical studies or works of linguists and previous researchers on the effects of bilingualism on the English of tertiary students and language learners generally. The chapter also $x$-rayed the meaning of mentorship and entrepreneurialship. The research went further in chapter three to carry out statistical data on the concerned population. Chapter four analyzed and interpreted the data, and finally recommendations and suggestions for further studies were made and conclusion drawn.

\subsection{RECOMMENDATIONS}

Based on the data analysis and interpretation, we make the following recommendations:

1. Parents should be encouraged to maintain bilingualism at home and encourage their children to use both languages in all areas of communication.

2. Language teachers should emphasize on areas of difficulty and interference and drill the students on the correct forms application.

3. Awareness should be created on the benefits of bilingualism to the students, teachers, society and all users of language, including business, law, legislature, religion, governance. 
4. Language laboratories in tertiary institutions should be properly equipped to enhance tertiary students' proficiency in English.

5. Textbook writers should lay more emphasis on these areas of difficulties.

6. Syllabus designers should take cognizance of these positive and negative effects of bilingualism on the students, ensure that students derive the positive benefit and also provide solutions to the negative effect to achieve proficiency.

7. Curriculum planners should ensure that bilingualism is maintained in the school curriculum at all levels.

8. The government should provide instructional materials and give enough financial aids to schools for English language teaching and learning.

\subsection{CONCLUSION}

From the data analysis and interpretation of this study, the researchers had come to conclude that Bilingualism affects the English of tertiary students both positively and results in rapid mentorship and entrepreneurial development. These effects include:

1. Bilingualism enhances and enriches the students' language experience and offers them insights and opportunities for developing cognitive skill for economic, political, religious, legislative and environmental awareness.

2. Bilingualism enhances the ability to interact in the two languages and the ability to transfer concepts from one language to the other.

3. Code-mixing and code-switching are influences of bilingualism and that students code-mix and code-switch most of the time to play down on their mother tongue.

4. That interference of the mother tongue (L1) at phonological, grammatical, and semantic levels can enhance proficiency in the English of tertiary students.

The researchers, therefore believe that if the recommendations are properly implemented, bilingualism should be a sine-qua-non for mentorship and entrepreneurial development.

\section{REFERENCES}

Akindele, F and Adegbite, W., 1999. The Sociology and Politics of English in Nigeria: Ibadan: OAU Press.

Anyanwa, P. A., 2002. ENGLIGBI "The Dynamics of English-lgbo Contact Situation" in African Journal of Language Research Vol.1 Nos 1 and 2, SIGGLO NIG. LTD. Kaduna, Nigeria.

Austin, J. L., 1962. How to do things with Words. Oxford: Clarendon Press.

Baker, C., 2006. Foundations of Bilingual Education and Bilingualism. Multilingual Matters, Clevedon.

Bialystok, E., 2001. Bilingualism in Development: Language, Literacy and Cognition. Cambridge: Cambridge University Press.

Fromkin, V and Rodman, R., 1978. An Introduction to Language. London: Rinehart and Winston.

Gal, S., 1978. "Peasant Men Can't Find Wives: Language Change and Sex Roles in a Bilingual Community". Language in Society. (7): 1-6.

Grice, H. P., 1975. Logic and Conversation in Cole, P. and J.L. Morgan (eds.) Speech Acts: Semantics and Syntax III. New York: Academic press 41-59.

Liddicoat, A., 2001. "Learning a Language, Learning about Language, Learning to be Literate". Babel, 35, (3): 12-15.

Liddicoat, A., 2002. "Static and Dynamic Views of Culture and Intercutural Language Acquisition". Babel, 36, (3): 4-11.

Nwachukwu, U. I., 2007. Challenges in the Teaching and Learning of English in Nigeria. Owerri: Cel-Bez and Co. Publishers.

Ogu, J. N., 1992. A Historical Survey of the Nigerian Situation. Lagos: Kraft Books Ltd. 
Osuafor, C. C., 2002. The English Language in Nigeria. Owerri: Great Versatile Publishers.

Searle, J., 1969. Speech Acts. Cambridge: Cambridge University Press.

Yule, G., 1996. The Study of Language. Cambridge: Cambridge University Press.

Wardhaugh, R., 2010. An Introduction to Sociolinguistics. $6^{\text {th }}$ ed. United Kingdom: Blackwell Publishers Ltd. 